\title{
Biochemical and biological activity of arginine deiminase from Streptococcus pyogenes M22.
}

\begin{tabular}{|r|l|}
\hline Journal: & Biochemistry and Cell Biology \\
\hline Manuscript ID & bcb-2015-0069.R1 \\
\hline Manuscript Type: & Article \\
\hline Date Submitted by the Author: & $11-$ Sep-2015 \\
\hline Complete List of Authors: & $\begin{array}{l}\text { Starikova, Eleonora; Institute for Experimental Medicine, Immunology } \\
\text { Sokolov, Alexey; Institute for Experimental Medicine, Molecular Genetic; } \\
\text { Saint-Petersburg State University } \\
\text { Vlasenko, Anna; Institute for Experimental Medicine, Molecular Genetic } \\
\text { Burova, Larisa; Institute for Experimental Medicine, Molecular Microbiology } \\
\text { Freidlin, Irina; Institute for Experimental Medicine, Immunology } \\
\text { Vasilyev, Vadim; Institute for Experimental Medicine, Molecular Genetic; } \\
\text { Saint-Petersburg State University }\end{array}$ \\
\hline Keyword: & $\begin{array}{l}\text { Streptococcus pyogenes type M22, arginine deiminase, cell proliferation, } \\
\text { endothelial cell }\end{array}$ \\
\hline \multicolumn{2}{|c}{} \\
\hline
\end{tabular}


Biochemical and biological activity of arginine deiminase from Streptococcus pyogenes M22.

Eleonora A. Starikova ${ }^{1}$, Alexey V. Sokolov ${ }^{1,2}$, Anna Yu. Vlasenko ${ }^{1}$, Larisa A. Burova ${ }^{1}$, Irina S. Freidlin $^{1}$, Vadim B. Vasilyev ${ }^{1,2}$

${ }^{1}$ Institute of Experimental Medicine, St. Petersburg, Russia

${ }^{2}$ Saint-Petersburg State University, St. Petersburg, Russia 
Streptococcus pyogenes (group A Streptococcus - GAS) is an important gram-positive extracellular bacterial pathogen responsible for a number of suppurative infections. This microorganism developed complex virulence mechanisms to avoid host defense. We have previously revealed that Supernatant of Destroyed Streptococcal Cells (SDSC) from GAS type M22 causes endothelial cells' dysfunction, inhibits cellular adhesion, migration, metabolism and proliferation in a dose-dependent manner without affecting cells' viability. The present work is aimed at isolation and characterization of a component from GAS type M22 supernatant that suppresses proliferation of endothelial cells EA.hy926. Isolating a protein possessing antiproliferative activity allowed identifying arginine deiminase (AD). Further study showed that the enzyme is most active at $\mathrm{pH}$ 6.8. Calculating $\mathrm{Km}$ and $\mathrm{V}_{\max }$ gave the values of $0.67 \mathrm{mM}$ and $42 \mathrm{~s}^{-1}$, respectively. Distinctive feature of AD purified from GAS type M22 is the closest to neutral $\mathrm{pH}$ optimum of activity and the maximal rate of the catalytic process compared with such of the enzyme from other microorganisms. AD from GAS type M22 suppressed the proliferative activity of endothelial cells in a dose-dependent mode. At the same time in the presence of AD the share of cells in $\mathrm{G}_{0} / \mathrm{G}_{1}$ phase increased. When L-Arg was added at increasing concentrations to the culture medium containing $3 \mu \mathrm{g} / \mathrm{ml} \mathrm{AD}$, the enzyme's capacity to inhibit cell proliferation became partly depressed. The proportion of cells in phases $S / G_{2}$ increased concomitantly, though the cells did not fully recover their proliferation activity. All this allows regarding AD from GAS type M22 as a prospective pharmacy for suppression of excessive cell proliferation.

Key words: Streptococcus pyogenes M22, arginine deiminase, endothelial cell proliferation.

ABBREVIATIONS: AD - arginine deiminase, GAS - Streptococcus pyogenes or group A streptococcus, SDSC - supernatant of destroyed streptococcal cells, eIF2 - Eukaryotic Initiation Factor 2, GCN2 - general control nonderepressible 2, HAT - hypoxanthineaminopterin-thymidine, PBS - phosphate-buffered saline, FITC - fluorescein isothiocyanate, HUVEC - human umbilical vein endothelial cells. 


\section{INTRODUCTION}

L-Arg is conditionally essential amino acid involved in a number of physiological processes (immunity, growth and regeneration). It is a precursor for the synthesis of L-ornithine, L-proline, polyamines, agmatine, creatine and proteins. Uncombined L-Arg is produced in an organism due to the endogenous synthesis from nutrients. It is a substrate of four enzymes i.e. NO synthases, arginases, arginine: glycineamidinetransferases, and L-Arg decarboxylases (Morris 2002). During the development of a bacterial infection, arginine becomes a substrate for bacterial arginine deiminase (AD) (Das et al. 2010). This enzyme is likely to be used by bacteria to disrupt the function of host cells. Bacterial AD is known to inhibit proliferation of various eukaryotic cells (Altucci et al. 1966; Claesson et al. 1990; Degnan et al. 1998; Kuo et al. 2010; Miyazaki et al. 1990; Park et al. 2003; Takaku et al. 1992; Gong et al. 1999, 2000; Fiedler et al. 2015). By now $\mathrm{AD}$ from a number of streptococcus strains has been isolated and characterized (Yosida et al. 1985, 1987, 1989, 1991, 1994; Degnan et al. 1998).

Our previous studies showed that there was a dose-dependent decrease in the inclusion of 5-5Bromo-2'-Deoxyuridine (synthetic analogue of thymidine) into the DNA of cells in the presence of Supernatant of destroyed streptococcal cells (SDSC) of $S$. pyogenes type M22. That was an indication of the decrease of the intensity of DNA synthesis and the intensity of cell proliferation. Analysis of cell cycle phases in the presence of SDSC revealed a significant increase of the proportion of cells in the resting phases $\mathrm{G}_{0} / \mathrm{G}_{1}$, while the proportion of cells in the phases of the synthesis $S / G_{2}$ was reduced. Further studies showed that culturing in the presence of SDSC inhibited the migration and adhesion of endothelial cells (Starikova et al. 2012). The study of the mechanisms underlying these effects showed that SDSC in the concentrations used did not exert cytotoxic and apoptogenic action on endothelial cells. A dose-dependent decrease of the activity of mitochondrial dehydrogenases was observed. The effect was reversible, i.e. removal of SDSC from the culture medium restored the cells' metabolism. In our experiments adding SDSC did not change the levels of phosphorylation of stress kinases NF- $\kappa \beta$, p38 and JNK, while phosphorylation of ERK1/2 and FAK became significantly reduced. The assumption was made that the active component responsible for the observed effect was AD.

The present work was aimed at isolation and characterization of a component of GAS type M22 supernatant that suppresses proliferation of endothelial cells EA.hy926.

\section{MATERALS AND METHODS}

Cell culture

Endothelial cells EA.hy 926 were a generous gift of Dr. Cora-Jean S. Edgell (University of North Carolina, USA). This cell line displays major phenotypic and functional features of 
endothelial cells from human large vessels (Edgell et al. 1983). Cells were cultured in DMEM (Sigma, USA) containing 10\% embryonic calf serum (Sigma, USA), HAT (Sigma, USA), 4 mM L-glutamine and $100 \mu \mathrm{g} / \mathrm{ml}$ gentamycin (Biolot, Russia). Subculturing was done twice a week. Cellular monolayer disintegration was induced by incubation in $0.02 \%$ solution of ethylene diamine tetra-acetic acid (EDTA) (Biolot, Russia).

\section{Obtaining supernatant of ultrasonic treated streptococci}

Supernatant of destroyed streptococcal cells (SDSC) by ultrasonic treatment containing active intracellular components was prepared using GAS type M22, strain AL168, generously provided by Dr. Lindahl (Department of Laboratory Medicine, University of Lund, Sweden). Strain was grown aerobically in Todd-Hewitt broth (Difco, USA) overnight at $37^{\circ} \mathrm{C}$. The cells then were centrifuged, and the pellet was twice washed with lipopolysaccharide-free phosphatebuffered saline (PBS).

Concentration of bacterial suspension was standardized by optical density to achieve 2.5$5 \times 10^{8} \mathrm{CFU} / \mathrm{ml}$. Portions of $5 \mathrm{ml}$ of suspension in PBS, pH 7.0, were sonicated at $22 \mathrm{kHz}$ and $0.6-$ $0.8 \mathrm{~mA}$ output in ultrasound disintegrator (MSE, U.K.). Completeness of disintegration of bacterial cells was controlled under microscope, after which the suspension was centrifuged at $16000 \mathrm{xg}$ for $30 \mathrm{~min}$. The supernatant was filtered through $0.45 \mu \mathrm{M}$ Filtropure $\mathrm{S}$ (Sarstedt, Germany) and stored at $-20^{\circ} \mathrm{C}$. Supernatant of bacterial components used in dilutions did not show toxic effect on cell cultures.

\section{Cells proliferation assay}

Proliferation activity of cells was assayed according to Cheong J.K. et al. 2011 with some modifications. Cells were seeded in 96-well tissue culture plates (Greiner, Austria) so that each well contained $5 \times 10^{3}$ cells in $100 \mu 1$ of complete culture medium, and incubated at $37^{\circ} \mathrm{C}$ in the presence of substances under study for $72 \mathrm{~h}$ in humid ambience containing $5 \% \mathrm{CO}_{2}$. Cells were then fixed and stained with $0.2 \%$ crystal violet dye (Sigma-Aldrich, USA) solution in $10 \%$ methanol for $10 \mathrm{~min}$. Excess crystal violet dye was removed by five washings with deionized water and the culture plates were dried overnight. Then cells were incubated in $10 \%$ acetic acid to release the dye, after which optical density of solutions was measured at $570 \mathrm{~nm}$ in an automatic spectrophotometer (Bio-Rad Laboratories).

\section{Flow cytometric analysis of the cell cycle}

Cells were seeded in the wells of flat-bottom 6-well plate (Nunc, USA). The amount of cells in complete culture medium was $5-6 \times 10^{5}$ per well. After that substances under study were introduced into the wells. $24 \mathrm{~h}$ later cells were transferred into microtubes and fixed/permeabilized for 5 min with $96 \%$ ice-cold methanol. This was followed by staining the cell suspension with FITC-conjugated anti-cyclin A2 antibodies (Beckman Coulter, USA). 
Staining was performed in accordance with the manufacturer's instructions. $2 \mu \mathrm{g} / \mathrm{ml}$ propidium iodide (Sigma, USA) and $100 \mu \mathrm{g} / \mathrm{ml}$ Ribonuclease A (Sigma, USA) were added to each sample. Samples were incubated for 20 minutes at room temperature in the dark. After incubation cell samples were analyzed using flow cytometer Navios (Beckman Coulter, USA).

Isolation and identification of the protein from SDSC capable of suppressing cell proliferation

To purify from SDSC the protein that suppresses cell proliferation, the supernatant was fractionated by ion-exchange and affinity chromatography. Fractions obtained at each stage were flown through $0.22 \mu \mathrm{m}$ filter, and their capacity to suppress cell proliferation was assayed. Only fractions that, upon dilution $1: 25$, induced a drop of proliferation at least to $50 \%$ were selected for further study. SDSC was diluted 1:5 with water and loaded on an UNO-Sphere S column $(20 \times 2.5 \mathrm{~cm})$ equilibrated with $\mathrm{PBS}$ diluted with water 1:5 $(\mathrm{PBS} / 5)$. Ballast proteins were removed by washing the column with $\mathrm{PBS} / 5$, which was followed by elution with two linear gradients, namely $40 \mathrm{ml}$ of $\mathrm{PBS} / 5 \rightarrow \mathrm{PBS}$ and $50 \mathrm{ml}$ of $\mathrm{PBS} \rightarrow 1 \mathrm{M} \mathrm{NaCl}$. Antiproliferation activity was detected in fractions eluted by gradients, but partly also in the fraction of ballast proteins washed out by PBS/5. All fractions were pooled and loaded on an UNO-Sphere S column $(18 \times 2.5 \mathrm{~cm})$ equilibrated with $\mathrm{PBS} / 5$. The column was washed again with $\mathrm{PBS} / 5$, after which the same two linear gradients were used for protein elution (see above). Antiproliferation activity was found in the fractions eluted with 150-200 $\mathrm{mM} \mathrm{NaCl}$. Those were diluted with water 1:5 and subjected to chromatography according to the same protocol. Once more the antiproliferation activity was found in the fractions eluted with 150-200 $\mathrm{mM} \mathrm{NaCl}$. The fractions were pooled and concentrated to the volume of $0.2 \mathrm{ml}$ in VivaSpin cells (retaining proteins above $30 \mathrm{kDa})$. This volume was loaded on a Sephacryl S-200 HR column $(115 \times 1 \mathrm{~cm})$ equilibrated with PBS. Antiproliferation activity was eluted by PBS and detected in fractions with proteins having approximate M 150-160 kDa. Again the fractions were pooled, concentrated to the volume of $0.2 \mathrm{ml}$ in VivaSpin cells (retaining proteins above $30 \mathrm{kDa}$ ) and subjected to electrophoresis in SDS-containing PAAG (10\% acrylamide). A protein with $\mathrm{M} \sim 45$ $\mathrm{kDa}$ was revealed, treated with trypsin, and its fragments were analyzed in a mass spectrometer.

To prepare a sample for mass spectrometry a piece of protein-containing gel $\left(1 \mathrm{~mm}^{3}\right)$ was cut out. That piece was destained by repeating twice its 30 -min incubation at $37^{\circ} \mathrm{C}$ in $100 \mu 1$ of $40 \%$ acetonitrile in $0.1 \mathrm{M} \mathrm{NH}_{4} \mathrm{HCO}_{3}$. Then PAAG was transferred into $100 \mu \mathrm{l}$ of acetonitrile for dehydration, after which it was taken out and dried. $4 \mu \mathrm{l}$ of modified trypsin in $0.05 \mathrm{M}$ $\mathrm{NH}_{4} \mathrm{HCO}_{3}(15 \mu \mathrm{g} / \mu \mathrm{l})$ were added to the gel. Hydrolysis lasted for $18 \mathrm{~h}$ at $37^{\circ} \mathrm{C}$, after which $8 \mu \mathrm{l}$ of $0.5 \%$ TFA in $10 \%$ water solution of acetonitrile were added and the content was thoroughly mixed. Gel particles were let precipitate and the supernatant was used to obtain MALDI mass 
spectra. $1 \mu \mathrm{l}$ of a sample obtained as described was mixed with $0.3 \mu 1$ of 2,5-dihydroxybenzoic acid $(10 \mathrm{ml} / \mathrm{ml}$ in $20 \%$ acetonitrile/water with $0.5 \%$ TFA), and the mixture obtained was dried in the air. Mass spectra were obtained in a tandem MALDI TOF-TOF spectrometer Ultraflex II BRUKER (Germany) supplemented with a UV laser (Nd). Mass spectra were registered using reflectron in a positive ion mode. Precision of the masses determined upon refinement on account of trypsin autolysis was $0.005 \%$. Peptide fingerprints thus obtained were analyzed online using MASCOT program (http://www.matrixscience.com). The search based on a peptide fingerprint was done with precision mentioned among the bacterial proteins using NCBI database. Possible oxidation of methionines in the open air and modification of cysteines by acrylamide were accounted for.

\section{Assaying the activity of arginine deiminase (AD)}

Our protocol of assaying the activity of arginine deiminase (AD) was based on the modified reaction of Sukaguchi that allows measuring the yellow-colored derivative of arginine upon its interaction with thymol and sodium hypobromite in basic medium (Sastry and Tummuru. 1984). Ammonium produced in that reaction, instead of the yellow color typical of arginine, gave blue staining (indophenol reaction).

To carry out the assay $100 \mu \mathrm{l}$ of $5 \mathrm{mM}$ arginine hydrochloride in PBS (150 mM NaCl, 10 $\mathrm{mM}$ Na-phosphate buffer, $\mathrm{pH}$ 7.4) were taken, to which a sample under study $(2.5,5$ or $10 \mu \mathrm{l})$ was added and incubated for $30 \mathrm{~min}$ at $37^{\circ} \mathrm{C}$. The reaction was stopped by adding $50 \mu \mathrm{l}$ of 100 $\mathrm{mM}$ thymol and $100 \mu \mathrm{l}$ of $40 \mathrm{mM}$ sodium hypobromite diluted in $2 \mathrm{M} \mathrm{NaOH}$. The reaction was run in 96-well plates, and the optical density was registered in a plate spectrometer at $450 \mathrm{~nm}$. Calibration curve reflecting the dependence of absorption at $450 \mathrm{~nm}$ on arginine concentration $(0.25-5.0 \mathrm{mM})$ was plotted for each separate experiment. Enzymatic activity was expressed as $\mu \mathrm{M}$ of arginine utilized by the enzyme with a correction for an added sample volume. Specific activity was related to the bulk protein $(\mathrm{mg})$.

To determine $\mathrm{Km}$ the amount of arginine utilized by $\mathrm{AD}$ was measured within the range of concentrations 1-3 mM in sodium-phosphate buffer, $\mathrm{pH} 6.8$ containing $1 \mu \mathrm{g} / \mathrm{ml}$ AD during 30 min. A graph in Hanes-Woolf coordinates [Arg]; [Arg]/V was plotted, $\mathrm{V}_{\max }$ and $\mathrm{Km}$ were calculated.

\section{Isolation of AD from SDSC}

To isolate AD several sequential chromatographies were used. First, SDSC diluted with water 1:5 was loaded on an UNO-Sphere Q column $(18 \times 2.5 \mathrm{~cm})$ equilibrated with $\mathrm{PBS} / 5$ and the ballast proteins were washed out with $\mathrm{PBS} / 5$. This was followed by elution with two linear gradients i.e. $40 \mathrm{ml}$ of PBS/5 $\rightarrow$ PBS and $50 \mathrm{ml}$ of PBS $\rightarrow 1 \mathrm{M} \mathrm{NaCl}$. The fractions displaying $\mathrm{AD}$ activity were concentrated to $0.7 \mathrm{ml}$ in a VivaSpin20 cell (retaining proteins from $30 \mathrm{kDa}$ ). 
This sample was loaded on a Sephacryl S-200 HR column $(115 \times 1 \mathrm{~cm})$ equilibrated with PBS. The fractions with AD activity were diluted with water 1:5 and applied on a column $(5 \times 1 \mathrm{~cm})$ with arginine-Sepharose equilibrated with PBS/5. Proteins were eluted with stepwise gradient, each step consisting of $5 \mathrm{ml}$ of PBS/5, PBS/4, PBS/3, PBS/2 and PBS. AD activity was found in the PBS/2 fraction that was concentrated in a VivaSpin20 cell to $1.2 \mathrm{ml}$. An aliquot of pure enzyme $(10 \mu \mathrm{g})$ was used for another analysis on mass spectrometer. $100 \mathrm{mg}$ of bovine serum albumin were added to the remaining $140 \mu \mathrm{g}$ of $\mathrm{AD}$ to stabilize the enzyme.

\section{Statistical analysis}

Experiments were repeated three times $(n=3)$ and the mean values were calculated as $\mathrm{X}_{\mathrm{m}}=(1 / \mathrm{n}) \Sigma \mathrm{X}_{\mathrm{i}}$, where $\mathrm{X}_{\mathrm{i}}$ is a value of each successive sample. The standard error was expressed as $\mathrm{S}^{*} / \mathrm{n}$, where $\mathrm{S}^{*}=\sqrt{\frac{\sum\left(X_{i}-X_{m}\right)^{2}}{(n-1)}}$, and the confidence interval was calculated as $\mathrm{X}_{\mathrm{m}} \pm\left(\mathrm{S}^{*} / \mathrm{n}^{1 / 2}\right) \mathbf{t}_{\mathrm{n}-1,1-\alpha / 2}$, for which $t$ was found in the table of values on condition that in our experiments $\alpha=0.05$.

\section{RESULTS}

Data on isolation from SDSC the protein possessing antiproliferative activity are summarized in Table 1. Analysis of mass spectra obtained for tryptic fragments of the 45-kDa band in PAAG revealed 9-10 peptides attributed to AD from various strains of GAS, M-types: 1, 2, 3, 4, 5, 6, 12, 18, 28 and 49 (Fig. 1, Table 2).

In the course of isolation, the protein demonstrated features (molecular mass, anionic character) that suggested its relation to an AD from some GAS strains, as judged by the data presented Degnan et al. 1998.

To reduce protein losses at purification we elaborated an arginine utilization-based assay of $\mathrm{AD}$ activity, done concurrently with the protein's isolation. The assay provided rapid detection of the AD-containing fractions. It is worth noting that, in contrast to arginine, ammonium produced in $\mathrm{AD}$-catalyzed reaction gave blue staining (indophenol reaction) upon mixing with alkaline solutions of thymol and hypobromite. The yellow/blue shift of the solution color was a handy and reliable indication that a sample contained $\mathrm{AD}$, but no other arginineutilizing enzyme. Calibration plots reflecting the changes of absorption at $\mathrm{A}_{630}$ and $\mathrm{A}_{450}$ upon reaction of arginine, citrulline and ammonium with thymol and hypobromite, show that utilization of arginine allows revealing $\mathrm{AD}$ activity in fractions with the most precision. Absorption of the arginine derivative at $450 \mathrm{~nm}$ was ten times stronger than absorption of the ammonium derivative at $630 \mathrm{~nm}$ (Fig. 2, $a, b)$. 
Ion-exchange chromatography on UNO-Sphere Q allowed eluting AD with 150-200 mM $\mathrm{NaCl}$. In the course of gel filtration its elution volume corresponded to that of proteins with $\mathrm{M}$ 150-160 kDa. When subjected to affinity chromatography, AD was eluted from arginineSepharose with $75 \mathrm{mM} \mathrm{NaCl}$. Data on the step-by-step purification of AD are summarized in Table 3. The yield of AD was 53\% as judged by the activity assay. Finally obtained $150 \mu \mathrm{g}$ of $\mathrm{AD}$ amounted to $0.026 \%$ of the whole protein, which means 2030 -fold purification.

Electrophoresis in SDS-containing PAAG showed that AD obtained is a homogeneous protein with $\mathrm{M} \sim 45 \mathrm{kDa}$ (Fig. 3).

A study of the $\mathrm{pH}$ optimum for revealing the $\mathrm{AD}$ activity showed that the enzyme is most active at $\mathrm{pH}$ 6.8. At this $\mathrm{pH}$ its activity is equal to $83 \%, 88 \%$ and $86 \%$ of the maximum $\mathrm{AD}$ activity at $\mathrm{pH} 6.4,7.2$ and 7.8, respectively. Allowing for $\mathrm{M} \sim 45 \mathrm{kDa}$, the turnover number $\left(\mathrm{k}_{\text {cat }}\right)$ for $\mathrm{AD}$ obtained was calculated as $35 \mathrm{~s}^{-1}$ (Fig. 2,c).

Calculating $\mathrm{Km}$ and $\mathrm{V}_{\max }$ according to the Hanes-Woolf plot (Fig 2, d) gave the values of $0.67 \mathrm{mM}$ and $42 \mathrm{~s}^{-1}$, respectively. Table 4 contains the comparison of characteristics of AD purified from $S$. pyogenes M22 with such of the enzyme from other microorganisms. It is seen that a distinctive feature of the enzyme obtained in our study is the closest to neutral $\mathrm{pH}$ optimum of activity and the maximal rate of the catalytic process.

Our preliminary study showed that SDSC taken at the latest non-toxic dilution 1:50 significantly decreased cell proliferation to $60 \%$ of that in the control culture (Fig. 4, grey columns). Adding L-Arg to cell culture evened the inhibitory effect of SDSC (Fig. 5, grey columns). L-Arg at concentration $4 \mathrm{mM}$ had the optimum effect. At increasing concentrations its capacity to restore cell proliferation went down.

AD isolated from SDSC suppressed the proliferative activity of endothelial cells in dosedependent mode (Fig. 4, black columns). In view that the initial SDSC contained $30 \mu \mathrm{g} / \mathrm{ml} \mathrm{AD}$ and that purified $\mathrm{AD}$ at concentrations $0.75 \mu \mathrm{g} / \mathrm{ml}$ and $0.375 \mu \mathrm{g} / \mathrm{ml}$ corresponded to SDSC diluted, respectively, to $1: 400$ and 1:200, it can be concluded that it is properly the activity of AD that underlies the antiproliferation effect of the SDSC. When L-Arg was added at increasing concentrations to the culture medium containing $3 \mu \mathrm{g} / \mathrm{ml} \mathrm{AD}$, the enzyme's capacity to inhibit cell proliferation became partly depressed, but the cells did not fully recover their proliferation activity (Fig. 5, black columns). On the one hand, this can be explained by the fact that L-Arg is not an inhibitor, but a substrate of AD. On the other hand, L-Arg itself improves cell proliferation, though at concentrations below $8 \mathrm{mM}$. This seems to be due to the toxicity of arginine or its metabolites (ammonia and citrulline), since an excess of L-Arg resulted in a drop of cell proliferation to the level observed in L-Arg-free samples. 
Studying the distribution of cells according to their cycling state showed that under standard culturing conditions, as well as when $4 \mathrm{mM}$ L-Arg was introduced into the medium, about $60 \%$ cells remained in $\mathrm{G}_{0} / \mathrm{G}_{1}$ state, while some $30 \%$ were in the state of synthesis $\mathrm{S} / \mathrm{G}_{2}$ (Fig. 6).

In the presence of SDSC the portion of cells in $\mathrm{G}_{0} / \mathrm{G}_{1}$ significantly increased to $80 \%$ with concomitant diminution of the share of cells in $\mathrm{S} / \mathrm{G}_{2}$ to $10 \%$. Similar, though less pronounced, changes (increased portion of $G_{0} / G_{1}$ cells and reduced portion of $S / G_{2}$ cells) were observed upon adding $3 \mu \mathrm{g} / \mathrm{ml} \mathrm{AD}$ to the culture medium.

\section{DISCUSSION}

The arginine deiminase system is widely spread among prokaryotes. It contains three principal enzymes i.e. $\mathrm{AD}$, ornithine-carbamoyltransferase and carbamate kinase. $\mathrm{AD}$ is a hydrolase converting L-Arg to $\mathrm{NH}_{3}$ and L-citrulline (Cunin et al. 1986). $\mathrm{NH}_{3}$ generated by L-Arg degradation increases $\mathrm{pH}$ in the environment, therefore, protects bacteria in conditions of high acidity (Fenske et al. 1976; Casiano-Colon and Marquis 1988; Gruening et al. 2006). Enzymes purified from several bacteria inhibit proliferation of different types of eukaryotic cells, malignant in that number. (Altucci et al. 1966; Claesson et al. 1990; Miyazaki et al. 1990; Takaku et al. 1992; Takaku et al. 1995; Komada et al. 1997; Degnan et al. 1998; Gong et al. 1999, 2000; Park et al. 2003; Kuo et al. 2010; Fiedler et al., 2015).

Like many prokaryotes, $S$. pyogenes expresses $\mathrm{AD}$ and antiproliferative activity of the enzyme expressed towards eukaryotic cells was demonstrated. The extract of S. pyogenes M5 (Manfredo strain) cells inhibited in dose-dependent manner the peripheral blood mononuclear leukocytes' proliferation, induced under the influence of superantigens and mitogens. Isolation and purification of the component responsible for the antiproliferative effect from the extract of $S$. pyogenes cells was performed. It was shown that the inhibitor had a molecular weight of about $100 \mathrm{kDa}$, and consisted of two identical subunits with a molecular mass of $47 \mathrm{kDa}$. $\mathrm{NH}_{2}$-terminal sequence of the protein showed up to 39.0\% amino acid homology with AD from Mycoplasma hominis, Mycoplasma arginini, Pseudomonas putida and Pseudomonas aeruginosa (Degnan et al. 1998). AD isolated from $S$. pyogenes (Su strain) at concentration $3 \mu \mathrm{g} / \mathrm{ml}$ decreased to $50 \%$ inclusion of labeled thymidine (Yosida et al. 1987), which indicated the inhibition of DNA synthesis in BALB/3T3 cells. AD from S. pyogenes M49 strain 591 heterologously expressed in E. coli efficiently reduced glioblastoma cell lines' proliferation (Fiedler et al. 2015).

The impact of AD on the endothelial cells' functions was studied only with the enzyme isolated from Mycoplasma arginini. Beloussow et al. showed that recombinant AD (rAD) from $M$. 
arginini, expressed in the E. coli inhibited the proliferation, migration, tube-like structure formation by human umbilical vein endothelial cells (HUVEC) in vitro (Beloussow et al. 2002). These data were confirmed by observations of Park et al. that rAD suppressed the vascular growth in vivo in the model of chicken chorioallantoic membrane and in the model of Matrigel plug assays in mouse (Park et al. 2003). It was shown that active rAD destroyed actin filaments in the endothelial tip cells, and thus deregulated and reduced their migration ability. The enzyme caused enhancement of reactive oxygen species' production and induced caspase 8-dependent apoptosis of endothelial cells (Zhou et al. 2011).

Our own studies have revealed that the SDSC of S. pyogenes type M22 reduced adhesion, proliferation, migration and metabolism of endothelial cell line EA.hy926 (Starikova et al. 2012). In this work isolation and characterization of the component responsible for the antiproliferative activity of SDSC were accomplished. Our study showed that suppression of proliferation of endothelial cells observed upon adding SDSC from S. pyogenes M22 occurred due to the activity of AD.

L-Arg depletion from the medium is likely to be a major factor of suppression of eukaryotic cells' proliferation in the presence of AD. An additional argument in favor of this statement is that the recovery of cell proliferation upon introducing exogenous L-Arg in the culture medium was observed. Deprivation of amino acids is known to entail the general nutritional starvation which, in turn, activates translation-inhibiting mechanisms in eukaryotic cells (Ye et al. 2010). Bulky evidence of the causal role of L-Arg deprivation in hampering cell proliferation has been accumulated (Saha and Kashina, 2011; Lee M. J., 2012). L-Arg deficiency caused by the activity of arginases results in activation of cytoplasmic GCN2 (general control nonderepressible 2) kinase in the presence of uncharged tRNA. It phosphorylates Ser51 in eIF2 $\alpha$, which is followed by the overall inhibition of translation and cell cycle arrest in $\mathrm{G}_{0} / \mathrm{G}_{1}$ (Wek et al. 1990, 1995; Ramirez et al. 1992; Graller and Boye 2007; Hamanaka et al. 2005). Cyclindependent cdk4 and cdk6 kinases in mammalian cells are associated with D-type cyclins (D1, D2 and D3) and regulate the transition from $G_{1}$ to $S$ phase of cell cycle. In case of L-Arg deficiency transcription of cyclin D3 mRNA goes down as well as stability of mRNA, and translocation of cyclin D3 to the nucleus becomes blocked (Raber et al. 2012; Morris 2012). These data can explain the results of our experiments in which adding L-Arg together with AD abrogated the anti-proliferative effect of the enzyme.

Despite the fact that adding exogenous arginine to the culture medium containing AD resulted in significant augmentation of endothelial cells' proliferation, the initial level was never recovered. The intensity of endothelial cells' proliferation in the presence of AD and L-Arg was significantly lower than in the presence of L-Arg alone, in all concentrations studied from 2 to 16 
$\mathrm{mM}$ (Fig. 5), which is consistent with the data obtained by Park et al., 2003. In our experiments high concentrations $(8-16 \mathrm{mM})$ of $\mathrm{L}-\mathrm{Arg}$ added to the medium containing $\mathrm{AD}$, unlike the lower ones, did not help cells to restore their proliferation, in contrast to the cells cultured in the absence of exogenous L-Arg. This indicates that cell proliferation went down affected by the LArg metabolites produced in reaction with AD. An important metabolite accumulated in culture medium as the result of L-Arg degradation by $\mathrm{AD}$, is $\mathrm{NH}_{3}$ (Komada et al. 1997; Miyazaki et al. 1990; Park et al. 2003). It seems likely that due to the high catalytic turnover of AD such concentrations of added L-Arg caused an increase of $\mathrm{NH}_{3}$ in the medium. Ammonia induces the production of reactive oxygen and nitrogen species that intoxicate cells in the medium (Norenberg et al. 2003, Bobermin et al. 2012). It can be suggested that $\mathrm{NH}_{3}$ can have similar toxic effect on the cells used in our study.

On the other hand the level of endothelial cells' proliferation after adding exogenous LArg in presence of AD did not reach the initial level due to the deficiency of L-Arg metabolites i.e. polyamines that should be produced upon its hydrolysis by eukaryotic arginase (Morrison et al. 1995, Morris 2009). Polyamines (small organic cations) seem to be essential for endothelial cell proliferation, even though the mechanism of their effect is not fully clear. They are supposed to play a role of importance for such fundamental cellular processes as signaling, replication and translation (Morrison et al. 1995; Li et al. 2002; Park et al. 2003; Rato et al. 2011; Landau et al. 2010). Thus, AD can affect protein synthesis not only by provoking amino acid starvation, but by inhibiting translation as well.

The AD from $S$. pyogenes type M22 purified in our study has high turnover $\left(35 \mathrm{~s}^{-1}\right)$ and the $\mathrm{pH}$ optimum (6.8) closest to that of human blood plasma (7.4). Its specific activity is no less than the activity of other AD microorganisms (Table 4). Lower activity of AD obtained from strain M49 expressed in E. coli DH5 $\alpha$ (Hering et al. 2013) can be explained by the differences in protein glycosylation or by incomplete oligomerization of the recombinant protein. Indeed, the attempts to obtain a recombinant SAGP resulted in the reduced activity of such protein (Kanaoka et al., 1991).

To our knowledge this study is the first to describe the isolation of $\mathrm{AD}$ from $S$. pyogenes type M22 and to present its characteristics. Besides, the enzyme obtained had a pronounced antiproliferative activity. Concentration of L-Arg in human plasma is $80-120 \mu \mathrm{mol} / \mathrm{L}$, which is of the same order that was maintained in the cultural medium during our experiments. In inflammation the need of L-Arg grows substantially (Morris 2009) and the conditions in our experiments (duration, AD content, L-Arg concentration), mimicking a case of infection, resulted in complete depletion of L-Arg in the medium. AD can be the pathogenic factor leading to L-Arg deficiency and endothelial dysfunction during streptococcal infection. At the same 
time the ability of this enzyme to inhibit the proliferation of endothelial cells allows regarding it as a likely antiangiogenic factor. Studying streptococcal AD is topical not only for understanding the L-Arg metabolism deregulation during bacterial infection, but also for obtaining efficient enzymes degrading L-Arg, with the aim of their use in treatment of pathological processes associated with enhanced angiogenesis (Hering et al., 2013).

\section{ACKNOWLEGMENTS}

This study was supported by the Program "Human Proteome".

\section{REFERENCES}

Aird W. C. 2007. Phenotypic Heterogeneity of the Endothelium: I. Structure, Function, and Mechanisms. Circ. Res. 100(2):158-73. PMID: 17272818

Altucci, P., Sapio, U., Coto, V., Esposito, E. and De Vargas, F. 1966. The arginine deiminase enzymatic test for the diagnosis of the presence of Mycoplasma in cell cultures. Boll. Soc. Ital. Biol. Sper. 42(19):1321-4. PMID: 5972604

Ashida H., Mimuro H., Ogawa M., Kobayashi T., Sanada T., Kim M., et al. 2011. Cell death and infection: A double-edged sword for host and pathogen survival. J. Cell Biol. 195(6):931-42. doi: 10.1083/jcb.201108081. PMID: 22123830

Beloussow K., Wang L., Wu J., Ann D., Shen W.C. 2002. Recombinant arginine deiminase as a potential anti-angiogenic agent. Cancer Lett. 183(2):155-62. PMID: 12065090

Bobermin L. D., Quincozes-Santos A., Guerra M. C., Leite M. C., Souza D. O., Goncalves C.-A., et al. 2012. Resveratrol Prevents Ammonia Toxicity in Astroglial Cells Plos one. 7(12):e52164. doi: 10.1371/journal.pone.0052164. PMID: 23284918

Carapetis J.R., Steer A.C., Mulholland E.K., Weber M. The global burden of group A streptococcal diseases. Lancet Infect Dis. 2005 Nov;5(11):685-94. PMID: 16253886

Casiano-Colon A. and Marquis R. E.. 1988. Role of the arginine deiminase system in protecting oral bacteria and an enzymatic basis for acid tolerance. Appl. Environ. Microbiol. 54(6):1318-24. PMID: 2843090. PMCID: PMC202656

Cheong J.K., Nguyen T.H., Wang H., Tan P., Voorhoeve P.M. , Lee S.H. et al. 2011. IC261 induces cell cycle arrest and apoptosis of human cancer cells viaCK1d/e and Wnt/bcatenin independent inhibition of mitotic spindle formation Oncogene. 30(22):2558-69. doi: 10.1038/onc.2010.627. PMID: 21258417. PMCID: PMC3109269

Claesson, M.H., Tscherning, T., Nissen, M.H. and Lind, K. 1990. Inhibitory effect of Mycoplasma-released arginase: activity in mixed-lymphocyte and tumour cell cultures. Scand. J. Immunol. 32(6):623-30. PMID: 2148642. 
Cunin, R., N. Glansdorff, A. Pierard, and V. Stalon. 1986. Biosynthesis and metabolism of arginine in bacteria. Microbiol. Rev. 50(3):314-52. PMID: 3534538. PMCID: PMC373073.

Cunnigham M. W. 2000. Pathogenesis of Group A Streptococcal Infections. Clin Microbiol Rev. 13(3): 470-511. PMCID: PMC88944.

Das P. ,Lahiri A. , Lahiri A. and Chakravortty D. 2010. Modulation of the Arginase Pathway in the Context of Microbial Pathogenesis: A Metabolic Enzyme Moonlighting as an Immune Modulator. PLoS Pathog. 6(6). e1000899. PMCID: PMC2887468.

Degnan, B. A., Palmer J. M., Robson T., Jones C. E., Fischer M.,. Glanville M, et al. 1998. Inhibition of human peripheral blood mononuclear cell proliferation by Streptococcus pyogenes cell extract is associated with arginine deiminase activity. Infect. Immun. 66(7): 30503058. PMCID: PMC108312

Edgell C.-J. S., McDonald C. C., and Graham J. B. 1983. Permanent cell line expressing human factor VIII-related antigen established by hybridization Nati Acad. Sci. USA. 80(12):3734-7. PMID: 6407019.

Ensor, C.M., Holtsberg, F.W., Bomalaski, J.S. et al. 2002. Pegylated arginine deiminase (ADI SS PEG20,000 mw) inhibits human melanomas and hepatocellular carcinomas in vitro and in vivo. Cancer Res. 62:5443-50. PMID: 12359751.

Fenske J.D., Kenny G.E. 1976. Role of arginine deiminase in growth of Mycoplasma hominis. J Bacteriol. 126(1):501-10. PMID: 1262306.

Fiedler T., Strauss M., Hering S., Redanz U., William D., Rosche Y., Classen C.F., Kreikemeyer B., Linnebacher M., Maletzki C. 2015. Arginine deprivation by arginine deiminase of Streptococcus pyogenes controls primary glioblastoma growth in vitro and in vivo. Cancer Biol Ther. 16(7):1047-55. doi: 10.1080

Gong H., Zölzer F., von Recklinghausen G., Rössler J., Breit S., Havers W., Fotsis T., Schweigerer L. 1999. Arginine deiminase inhibits cell proliferation by arresting cell cycle and inducing apoptosis. Biochem Biophys Res Commun. 261(1):10-4. PMID: 10405315.

Gong H., Zцlzer F., von Recklinghausen G., Havers W., Schweigerer L. 2000. Arginine deiminase inhibits proliferation of human leukemia cells more potently than asparaginase by inducing cell cycle arrest and apoptosis. Leukemia. 14(5):826-9. PMID: 10803513.

Gong H., Zцlzer F., von Recklinghausen G., Rцssler J., Breit S., Havers W., et al. 1999. Arginine deiminase inhibits cell proliferation by arresting cell cycle and inducing apoptosis. Biochem. Biophys. Res. Commun. 261(1):10-4. PMID: 10405315.

Grallert B., Erik B. 2007. The Gcn2 kinase as a cell cycle regulator. Cell Cycle.6(22):2768-72. PMID:17986863

Gruening P., Fulde M, Valentin-Weigand P, Goethe R. 2006. Structure, regulation, and putative function of the arginine deiminase system of Streptococcus suis. J. Bacteriol. 188(2):361-9. PMID: 16385025. PMCID: PMC1347268. 
Hamanaka R.B., Bennett B.S., Cullinan S.B., Diehl J.A. 2005. PERK and GCN2 contribute to eIF2 \{alpha\}phosphorylation and cell cycle arrest after activation of the unfolded protein response pathway. Molecular Biology of the Cell.16(5):493-501. PMID:16176978

Hering S., Sieg A., Kreikemeyer B., Fiedler T. 2013. Kinetic characterization of arginine deiminase and carbamate kinase from Streptococcus pyogenes M49. Protein Expr. Purif. 91(1):61-8. doi: 10.1016/j.pep.2013.07.002. PMID: 23867361.

Kanaoka M., Negoro T., Kawanaka C., Agui H., Nabeshima S. 1991. Streptococcal antitumor protein: expression in Escherichia coli cells and properties of the recombinant protein. Agric. Biol. Chem. 55(3):743-50. PMID: 1368629.

Kelly M.P., Jungbluth A.A., Wu B.W., Bomalaski J., Old L.J., Ritter 2012. Arginine deiminase PEG20 inhibits growth of small cell lung cancers lacking expression of argininosuccinate synthetase. G. Br. J. Cancer. 106(2):324-32. doi: 10.1038/bjc.2011.524. PMID: 22134507. PMCID: PMC326168

Kim R.H., Coates J.M., Bowles T.L., McNerney G.P., Sutcliffe J., Jung J.U., et al. 2009. Arginine deiminase as a novel therapy for prostate cancer induces autophagy and caspaseindependent apoptosis. Cancer Res. 69(2):700-8. doi: 10.1158/0008-5472.CAN-08-3157. PMID: 19147587 PMCID: PMC262938.

Komada Y., Zhang X.L., Zhou Y.W., Ido M., Azuma E. 1997. Apoptotic cell death of human $\mathrm{T}$ lymphoblastoid cells induced by arginine deiminase. Int J Hematol. 65(2):129-41. PMID: 9071817.

Kuo M.T., Savaraj N., Feun L.G. 2010. Targeted cellular metabolism for cancer chemotherapy with recombinant arginine-degrading enzymes. Oncotarget. 1(4):246-51. PMID: 21152246. PMCID: PMC2998341

Landau G., Bercovich Z., Park M. H., and Kahana C. 2010. The Role of Polyamines in Supporting Growth of Mammalian Cells Is Mediated through Their Requirement for Translation Initiation and Elongation Biol. Chem. 285(17):12474-81. doi: 10.1074/jbc.M110.106419. PMID: 20181941. PMCID: PMC2857121

Lee M.J., Kim D.E., Zakrzewska A, Yoo Y.D., Kim S.H., Kim S.T., Seo J..W, Lee Y..S, Dorn G.W.2nd, Oh U., Kim B..Y, Kwon Y.T. 2012. Characterization of Arginylation Branch of N-end Rule Pathway in G-protein-mediated Proliferation and Signaling of Cardiomyocytes, The Journal of Biological Chemistry 287(28). 24043-24052. PMID:22577142

Lemichez E., Lecuit M., Nassif X. and Bourdoulous S. 2010. Breaking the wall: targeting of the endothelium by pathogenic bacteria Nature Rewiews Microbiology. 8(2):93-104. doi: 10.1038/nrmicro2269. PMID: 20040916.

Li H., Meininger C.J., Kelly K.A., Hawker J.R. Jr, Morris S.M. Jr, Wu G. 2002. Activities of arginase I and II are limiting for endothelial cell proliferation. Integr Comp Physiol. Am. J. Physiol. Regul. PMID: 11742824

Miyazaki K., Takaku H., Umeda M., Fujita T., Huang W., Kimura T., et al. 1990. Potent Growth Inhibition of Human Tumor Cells in Culture by Arginine Deiminase Purified from a 
Culture Medium of a Mycoplasma-infected Cell Line Cancer Research. 50(15):4522-7. PMID: 2164440.

Morris S.M. Jr. 2012. Arginases and arginine deficiency syndromes. Curr. Opin. Clin. Nutr. Metab. Care. 15(1):64-70. doi: 10.1097/MCO.0b013e32834d1a08. PMID: 22037011. PMCID: PMC3268370.

Morris S.M. Jr. 2002. Regulation of enzymes of the urea cycle and arginine metabolism. Annu Rev Nutr. 22:87-105. PMID: 12055339.

Morris S.M. Jr. 2009. Recent advances in arginine metabolism: roles and regulation of the arginases British Journal of Pharmacology. 157(6):922-30. doi: 10.1111/j.14765381.2009.00278.x. PMID: 19508396. PMCID: PMC2737650.

Morrison R.F., Seidel E.R. 1995. Vascular endothelial cell proliferation: regulation of cellular polyamines. Cardiovasc Res. 29(6):841-7. PMID:7656288

Norenberg M.D. 2003. Oxidative and nitrosative stress in ammonia neurotoxicity. Hepatology 37(2):245-8. PMID: 12540772.

Park I.-S., Kang S.-W. , Shin Y.-J., Chae K.-Y., Park M.-O., Kim M.-Y., et al. 2003. Arginine deiminase: a potential inhibitor of angiogenesis and tumour growth British Journal of Cancer. 89(5):907-14. PMID: 12942125. PMCID: PMC2394481.

Raber P., Ochoa A. C., and Rodrhguez P. C. 2012. Metabolism of L-Arginine by Myeloid-Derived Suppressor Cells in Cancer: Mechanisms of T cell suppression and Therapeutic Perspectives Immunol Invest. 41(6-7):614-34. doi: 10.3109/08820139.2012.680634. PMID: 23017138. PMCID: PMC3519282.

Ramirez M., Wek R.C., Vazquez de Aldana C.R., Jackson B.M., Freeman B., Hinnebusch A.G. 1992. Mutations activating the yeast eIF-2 alpha kinase GCN2: isolation of alleles altering the domain related to histidyl-tRNA synthetases. Mol Cell Biol. 12(12):5801-15. PMID: 1448107. PMCID: PMC360520.

Rato C., Amirova S. R., Declan G. B., Stansfield I., and Wallace H. M. 2011. Translational recoding as a feedback controller: systems approaches reveal polyamine-specific effects on the antizyme ribosomal frameshift Nucleic Acids Res. 39(11):4587-97. doi: 10.1093/nar/gkq1349. PMID: 21303766. PMCID: PMC3113565.

Saha S. and Kashina A. 2011. Posttranslational Arginylation as a Global Biological Regulator. Dev. Biol. 358(1):1-8. doi: 10.1016/j.ydbio.2011.06.043. PMID: 21784066. PMCID: PMC3171647.

Sastry C. S. P., Tummuru M. K. 1984. Spectrophotometric determination of arginine in proteins. Food Chemistry. 15(4):257-60. doi: 10.1016/0308-8146(84)90110-9.

Savaraj N., Wu C., Kuo M., You M., Wangpaichitr M., Robles C., at al. 2007. The relationship of arginine deprivation, argininosuccinate synthetase and cell death in melanoma. Drug Target Insights. 2:119-28. PMID: 21901069. PMCID: PMC3155228. 
Savaraj N., You M., Wu C., Wangpaichitr M., Kuo M.T., Feun L.G. 2010. Arginine deprivation, autophagy, apoptosis (AAA) for the treatment of melanoma. Curr Mol Med. 10(4):405-12. PMID: 20459375. PMCID: PMC3096550.

Starikova E.A., Lebedeva A.M., Burova L.A., Freidlin I.S. 2012. Regulation of endothelial cells functions by ultrasonic supernatant of Streptococcus pyogenes. Tsitologiia. 54(1):49-57. PMID: 22567900

Takaku H., Matsumoto M., Misawa S., Miyazaki K. 1995. Anti-tumor activity of arginine deiminase from Mycoplasma argini and its growth-inhibitory mechanism. Jpn J Cancer Res. Sep;86(9):840-6.

Takaku H., Takase M., Abe S., Hayashi H., Miyazaki K. 1992. In vivo anti-tumor activity of arginine deiminase purified from Mycoplasma arginini. Int J Cancer. 51(2):244-9. PMID: 1568792

Takaku H., Takase M., Abe S., Hayashi H., Miyazaki K. 1992. In vivo anti-tumor activity of arginine deiminase purified from Mycoplasma arginini. Int. J. Cancer. 51(2):244-9. PMID: 1568792.

Wek R.C., Ramirez M., Jackson B.M., Hinnebusch A.G. 1990. Identification of positiveacting domains in GCN2 protein kinase required for translational activation of GCN4 expression. Mol. Cell Biol. 10(6):2820-31. PMID: 2188100. PMCID: PMC360643.

Wek S.A., Zhu S., Wek R.C. 1995. The histidyl-tRNA synthetase-related sequence in the eIF-2 alpha protein kinase GCN2 interacts with tRNA and is required for activation in response to starvation for different amino acids. Mol Cell Biol. 15(8):4497-506. PMID: 7623840. PMCID: PMC230689.

Ye J., Kumanova M., Hart L. S., Sloane K., Zhang H., Panis D. N., at al. 2010. The GCN2-ATF4 pathway is critical for tumour cell survival and proliferation in response to nutrient deprivation. The EMBO Journal. 29(12):2082-96. doi: 10.1038/emboj.2010.81. PMID: 20473272. PMCID: PMC2892366.

Yoon, C.Y., Shim, Y.J., Kim, E.H. et al. 2007. Renal cell carcinoma does not express argininosuccinate synthetase and is highly sensitive to arginine deprivation via arginine deiminase. Int. J. Cancer, 120:897-905. PMID: 17096330

Yoshida J., Takamura S. and Suzuki S. 1987. Cell growthinhibitory action of SAGP, an antitumor glycoprotein from Streptococcus pyogenes (Su strain). Jpn. J. Pharmacol. 45(2):143-7. PMID: 3325668.

Yoshida J., Takamura S. and Suzuki S. 1989. A simplified method for purification of an antitumor acidic glycoprotein from Streptococcus pyogenes (Su strain) by immunoadsorbent chromatography. J. Antibiotics. 45(2):143-7. PMID: 3325668.

Yoshida J., Takamura S. and Suzuki S. 1991. Antitumor action of an acidic glycoprotein (SAGP) from Streptococcus pyogenes in mice. Biotherapy. 3(4):331-6. PMID: 1786196. 
Yoshida J., Takamura S. and Suzuki S. 1994. Evidence for the involvement of sulfhydryl groups in the expression of antitumor activity of streptococcal acid glycoprotein (SAGP) purified from crude extract of Streptococcus pyogenes. Anticancer Res. 14(5A):1833-7. PMID: 7847816.

Yoshida J., Yoshimura M., Takamura S. and Kobayashi S.. 1985. Purification and characterisation of an antitumor principle from Streptococcus hemolyticus ( $\mathrm{Su}$ strain). Jpn. J. Cancer Res. 76(3):213-23. PMID: 3922840.

Zhuo W., Song X., Zhou H., Luo Y. 2011. Arginine deiminase modulates endothelial tip cells via excessive synthesis of reactive oxygen species. Biochem Soc Trans. 39(5):1376-81. doi: 10.1042/BST0391376.

\section{LEGENDS TO FIGURES}

Fig. 1. Mass spectrum of trypsin-digested $45-\mathrm{kDa}$ protein possessing antiproliferative activity isolated from SDSC (Table 1).

Fig. 2. Calibration plot of the changes of $A_{450}(a)$ and $A_{630}(b)$ for arginine, citrulline and ammonium occurring upon their reaction with thymol and sodium hypobromite. Plot [Arg]; V (c) and Hanes-Woolf plot [Arg]; [Arg]/V (d) within the range of Arg concentrations 1-3 mM in sodium-phosphate buffer, $\mathrm{pH} 6.8$ containing $1 \mu \mathrm{g} / \mathrm{ml}$ AD.

Fig. 3. Results of electrophoresis in SDS-containing PAAG. 1 - molecular mass markers, 2 - SDSC, 3 - a fraction displaying AD activity, eluted from UNO-Sphere Q, 4 - AD-containing fraction eluted from Sephacryl S-200 HR, 5 - AD obtained by affinity chromatography on arginine-Sepharose. Arrows mark M, kDa.

Fig. 4. Proliferative activity of the cell line EA.hy 926 in the presence of SDSC (grey columns) and in the presence of $\mathrm{AD}$ (black columns). Asterisk marks the statistically significant difference between the proliferative activity of the cell line EA.hy 926 in control group and the proliferative activity of the cell line EA.hy 926 in the presence of $\operatorname{SDSC}, \mathrm{p}<0.05$. Grid marks the significant difference between the proliferative activity of the cell line EA.hy 926 in control group and the proliferative activity of the cell line EA.hy 926 in the presence of $\mathrm{AD} p<0.05$.

Fig. 5. Proliferative activity of the cell line EA.hy 926 in the presence of L-Arg (white columns), in the presence of both L-Arg and SDSC 1:50 (grey columns), and in the presence of $\mathrm{L}-\mathrm{Arg}$ and $3 \mu \mathrm{g} / \mathrm{ml} \mathrm{AD}$ (black columns). Asterisk marks the significantly higher cell proliferation in the presence of L-Arg than in the presence of both L-Arg and SDSC. Grid marks the significantly higher cell proliferation in the presence of L-Arg than in the presence of both LArg and AD.

Fig. 6. Distribution of EA.hy 926 cells according to their cycling state upon 24-hr culturing in: a) culture medium, isotype control; b) culture medium (control); c) culture medium with SLS 1:50; d) culture medium with $3 \mu \mathrm{g} / \mathrm{ml} \mathrm{AD;} \mathrm{e)} \mathrm{culture} \mathrm{medium} \mathrm{with} 4 \mathrm{mM}$ L-Arg; f) 
culture medium with SLS 1:50 and $4 \mathrm{mM} \mathrm{L-Arg;} \mathrm{g)} \mathrm{culture} \mathrm{medium} \mathrm{with} 3 \mu \mathrm{g} / \mathrm{ml}$ AD and $4 \mathrm{mM}$ L-Arg. Asterisk marks the statistically significant difference from the control, $\mathrm{p}<0.05$. 
Table 1. Stepwise purification from SDSC of a protein with anti-proliferative activity

\begin{tabular}{|l|l|l|}
\hline Step & $\begin{array}{l}\text { Volume, } \\
\mathrm{ml}\end{array}$ & Protein, mg \\
\hline 1. SDSC & 10 & 274 \\
\hline 2. Chromatography on UNO-Sphere S & 80 & 187 \\
\hline 2. Chromatography on UNO-Sphere Q & 15 & 8.6 \\
\hline 3. Chromatography on UNO-Sphere Q & 15 & 1.8 \\
\hline 4. Concentration in VivaSpin20 & 0.2 & 1.2 \\
\hline 5. Gel filtration on Sephacryl S-200 HR & 5 & 0.05 \\
\hline 6. Concentration in VivaSpin20 & 0.2 & 0.04 \\
\hline
\end{tabular}


Table 2. Peptide fingerprint of the purified protein with anti-proliferative activity. Search results using MASCOT http://www.matrixscience.com. Start-end amino acids correspond to the sequence Arginine deiminase OS=Streptococcus pyogenes type M2

\begin{tabular}{|l|l|l|l|l|l|}
\hline Start-End & Observed & $\mathrm{Mr}(\mathrm{expt})$ & $\mathrm{Mr}($ calc) & Delta & Peptide \\
\hline $39-52$ & 1663.8486 & 1662.8413 & 1662.8505 & -0.0092 & R.LLFDDIPFLEDAQK.E \\
\hline $194-206$ & 1489.7577 & 1488.7504 & 1488.7514 & -0.0010 & K.YIFTHHPIYGGGK.V \\
\hline $230-239$ & 1057.5761 & 1056.5688 & 1056.5928 & -0.0239 & K.DVLAVGISQR.T \\
\hline $248-254$ & 846.5348 & 845.5275 & 845.5375 & -0.0099 & K.LLVNIFK.Q \\
\hline $255-260$ & 706.3895 & 705.3822 & 705.3810 & 0.0013 & K.QNLGFK.K \\
\hline $262-271$ & 1180.6059 & 1179.5986 & 1179.6036 & -0.0050 & K.VLAFEFANNR.K \\
\hline $300-316$ & 2081.0156 & 2080.0083 & 2080.0000 & 0.0083 & R.VYSVTYDNEELHIIEEK.G \\
\hline $332-336$ & 615.3856 & 614.3783 & 614.3752 & 0.0032 & K.VDLIR.C \\
\hline $387-394$ & 910.5106 & 909.5033 & 909.5032 & 0.0001 & K.IHGSELVR.G \\
\hline $401-408$ & 1000.4135 & 999.4062 & 999.3976 & 0.0086 & R.CMSMPFER.E \\
\hline
\end{tabular}


Table 3. Stepwise purification of AD from SDSC

\begin{tabular}{|l|l|l|l|l|l|l|}
\hline Step & $\begin{array}{l}\text { Volume, } \\
\mathrm{ml}\end{array}$ & $\begin{array}{l}\text { Protein, } \\
\mathrm{mg}\end{array}$ & $\begin{array}{l}\text { Overall } \\
\text { activity, } \\
\mu \mathrm{mol} \\
\text { Arg/min }\end{array}$ & $\begin{array}{l}\text { Specific } \\
\text { activity, } \\
\mu \mathrm{mol} \\
\text { Arg/min/mg } \\
\text { protein }\end{array}$ & $\begin{array}{l}\text { Purification, } \\
\text { fold }\end{array}$ & $\begin{array}{l}\text { Yield, } \\
\%\end{array}$ \\
\hline 1. SDSC & 20 & 578 & 13.3 & 0.023 & - & 100 \\
\hline $\begin{array}{l}\text { 2. Chromatography } \\
\text { on UNO-Sphere Q }\end{array}$ & 30 & 15.7 & 10.6 & 0.68 & 30 & 80 \\
\hline $\begin{array}{l}\text { 3. Gel filtration on } \\
\text { Sephacryl S-200 HR }\end{array}$ & 15 & 3.2 & 8.4 & 2.63 & 114 & 63 \\
\hline $\begin{array}{l}\text { 4.Affinity } \\
\text { Chromatography on } \\
\text { arginine-Sepharose }\end{array}$ & 5 & 0.16 & 7.2 & 45 & 1956 & 54 \\
\hline $\begin{array}{l}\text { 5. Concentration in } \\
\text { VivaSpin20 }\end{array}$ & 1.2 & 0.15 & 7 & 46.7 & 2030 & 53 \\
\hline
\end{tabular}


Table 4. Parameter of AD obtained as compared to those from the literature. http://www.brendaenzymes.org/enzyme.php?ecno=3.5.3.6 and Hering et al. 2013

\begin{tabular}{|l|l|l|l|l|l|}
\hline AD from & $\begin{array}{l}M, \\
\mathrm{kDa}\end{array}$ & $\mathrm{k}_{\text {cat }}, \mathrm{s}^{-1}$ & $\begin{array}{l}\text { Specific } \\
\text { activity, } \mu \mathrm{mol} \\
\text { Arg/min/mg } \\
\text { protein }\end{array}$ & $\begin{array}{l}\text { Optimum } \\
\mathrm{pH}\end{array}$ & Km, mM \\
\hline GAS type M22 & 45 & 35 & 46.7 & 6.8 & 0.67 \\
\hline GAS type M49 & 47 & - & 1.5 & 6.5 & 1.33 \\
\hline Bacilus cereus & - & 3.2 & - & 7.0 & 0.06 \\
\hline Mycoplasma arthritidis & 80 & 29 & 27 & 6.5 & 10 \\
\hline Pseudomonas plecoglossicida & 47 & 5.6 & 4.76 & 6 & 2.9 \\
\hline Mycoplasma arginini & 90 & - & 44.5 & 6 & 0.2 \\
\hline
\end{tabular}




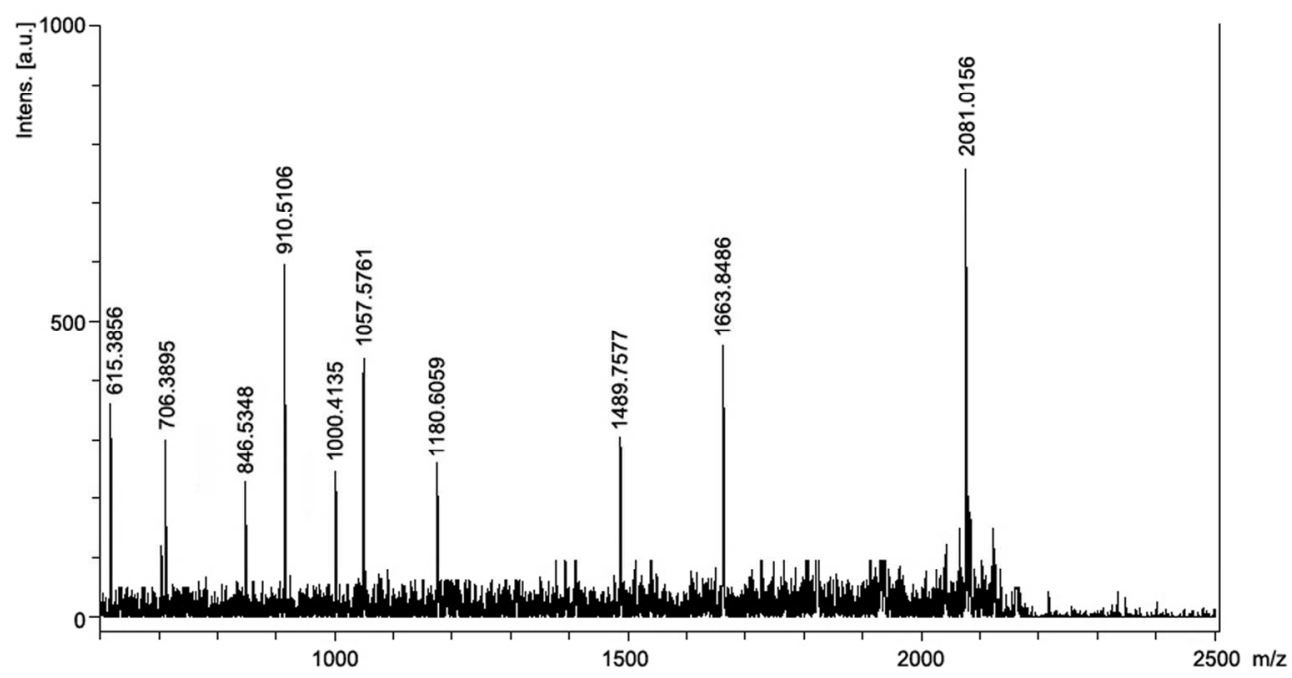

Fig. 1. Mass spectrum of trypsin-digested $45-k D a$ protein possessing antiproliferative activity isolated from SDSC (Table 1).

$130 \times 71 \mathrm{~mm}(300 \times 300 \mathrm{DPI})$ 

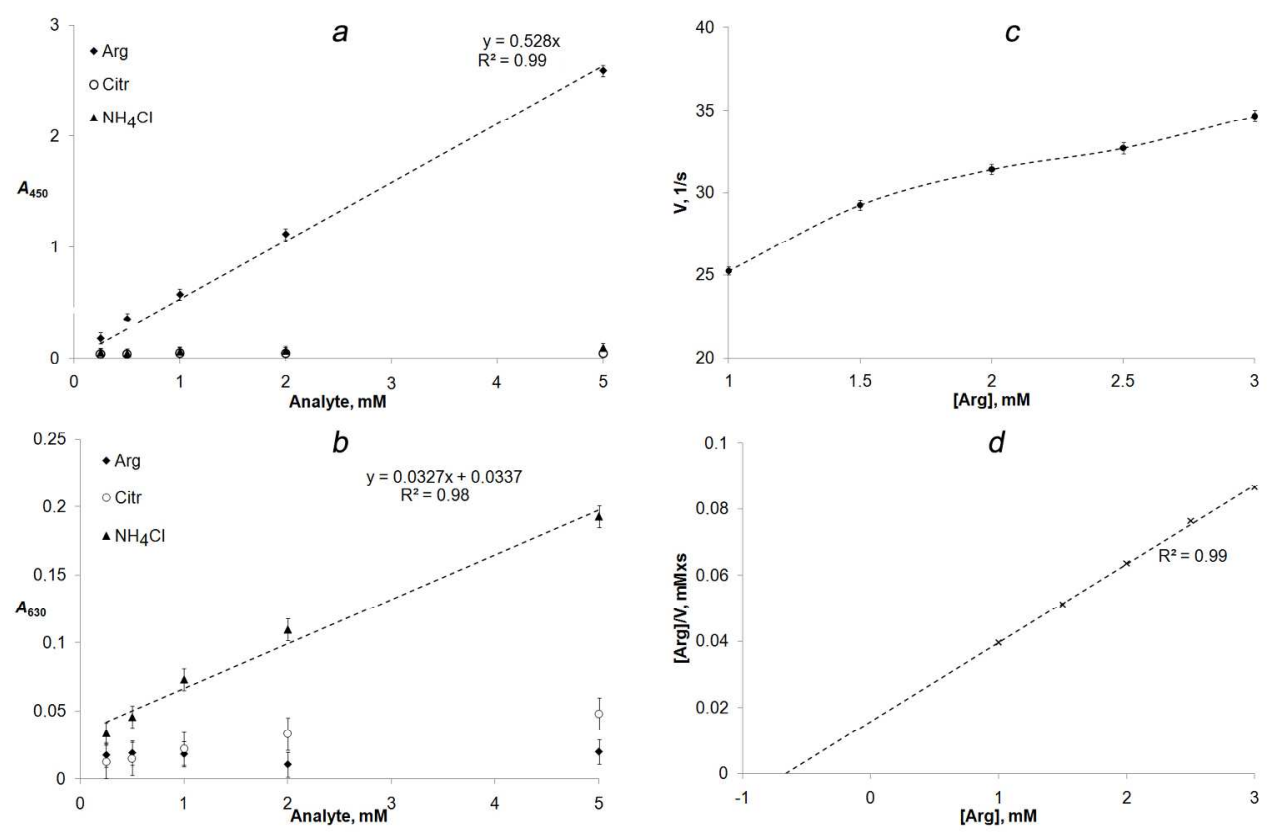

Fig. 2. Calibration plot of the changes of $A 450$ (a) and $A 630$ (b) for arginine, citrulline and ammonium occurring upon their reaction with thymol and sodium hypobromite. Plot [Arg]; $V(c)$ and Hanes-Woolf plot $[\mathrm{Arg}] ;[\mathrm{Arg}] / \mathrm{V}(\mathrm{d})$ within the range of Arg concentrations 1-3 mM in sodium-phosphate buffer, $\mathrm{pH} 6.8$ containing $1 \mu \mathrm{g} / \mathrm{ml} \mathrm{AD}$.

$738 \times 483 \mathrm{~mm}(72 \times 72 \mathrm{DPI})$ 


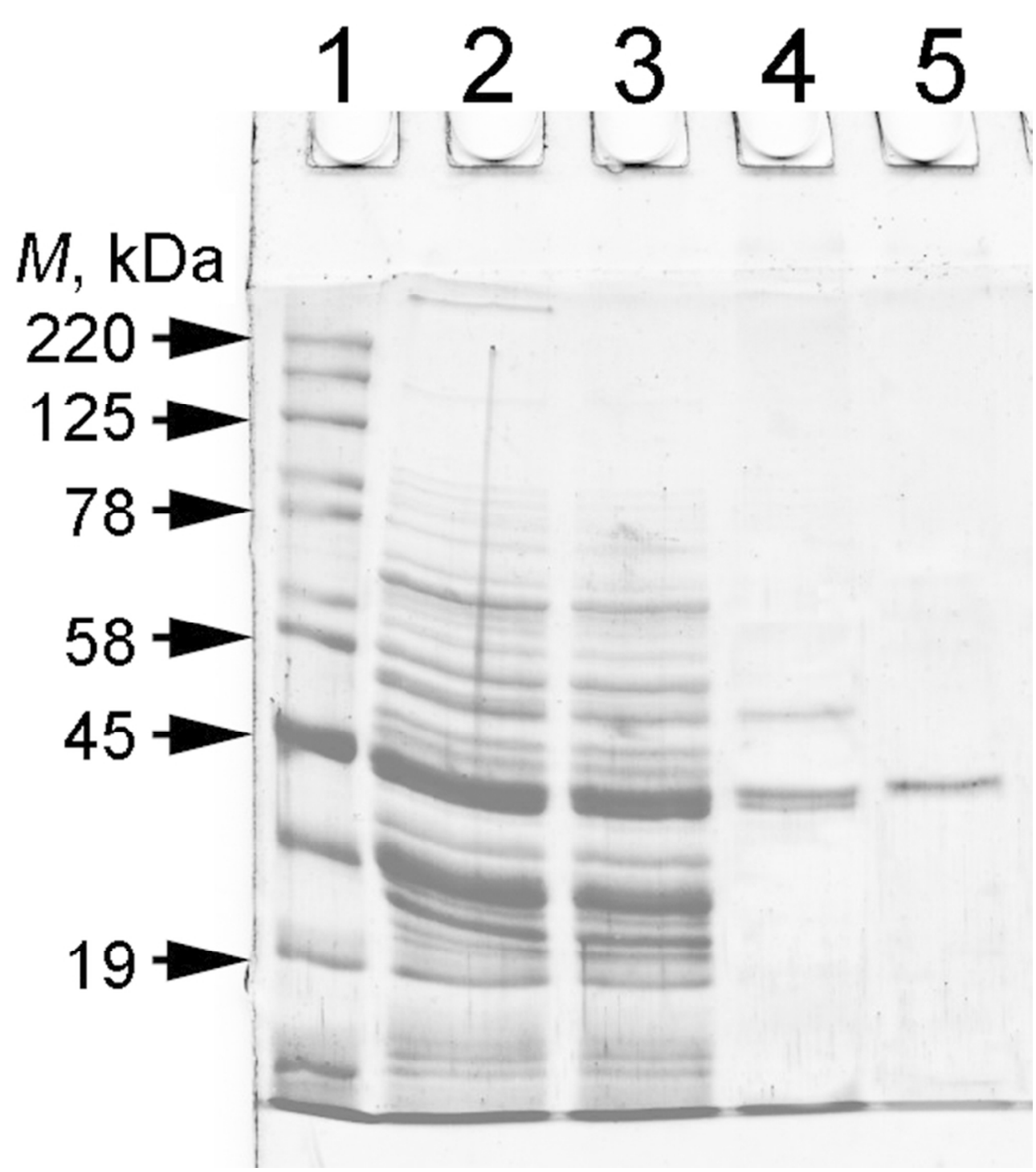

Fig. 3. Results of electrophoresis in SDS-containing PAAG. 1 - molecular mass markers, 2 - SDSC, 3 - a fraction displaying $A D$ activity, eluted from UNO-Sphere $Q, 4-A D$-containing fraction eluted from Sephacryl S-200 HR, 5 - AD obtained by affinity chromatography on arginine-Sepharose. Arrows mark M, kDa. $74 \times 85 \mathrm{~mm}(300 \times 300$ DPI $)$ 


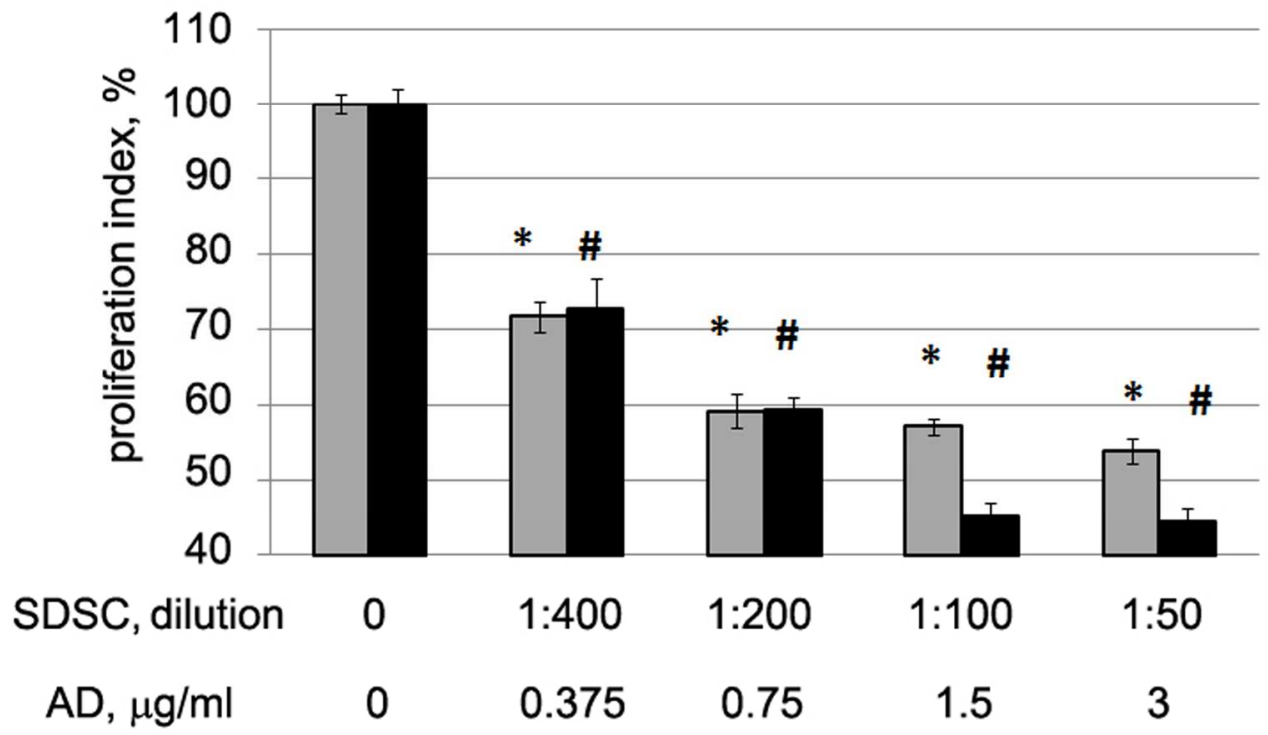

Fig. 4. Proliferative activity of the cell line EA.hy 926 in the presence of SDSC (grey columns) and in the presence of $A D$ (black columns). Asterisk marks the statistically significant difference between the proliferative activity of the cell line EA.hy 926 in control group and the proliferative activity of the cell line EA.hy 926 in the presence of SDSC, $p<0.05$. Grid marks the significant difference between the proliferative activity of the cell line EA.hy 926 in control group and the proliferative activity of the cell line EA.hy 926 in the presence of $A D p<0.05$.

$161 \times 100 \mathrm{~mm}(300 \times 300 \mathrm{DPI})$ 


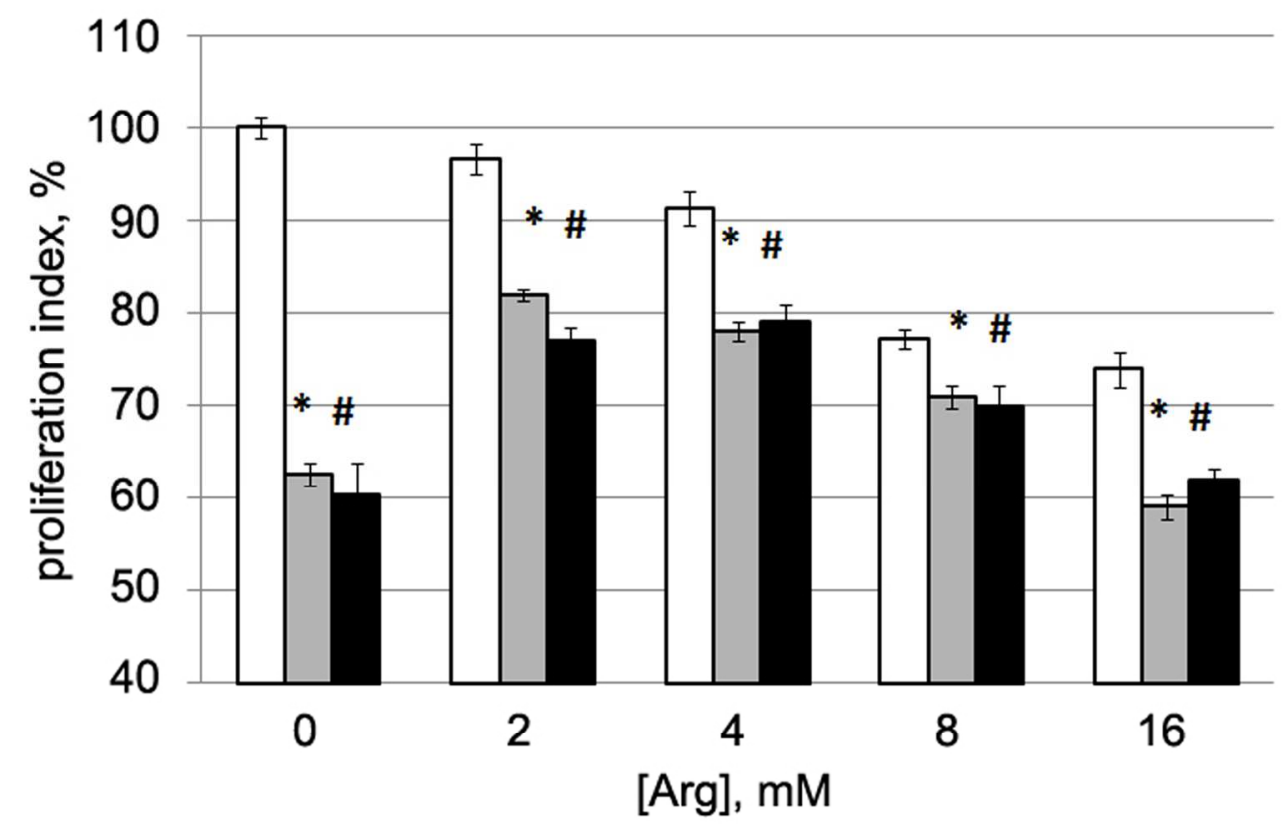

Fig. 5. Proliferative activity of the cell line EA.hy 926 in the presence of L-Arg (white columns), in the presence of both L-Arg and SDSC 1:50 (grey columns), and in the presence of L-Arg and $3 \mu \mathrm{g} / \mathrm{ml} \mathrm{AD} \mathrm{(black}$ columns). Asterisk marks the significantly higher cell proliferation in the presence of L-Arg than in the presence of both L-Arg and SDSC. Grid marks the significantly higher cell proliferation in the presence of LArg than in the presence of both L-Arg and AD. $161 \times 106 \mathrm{~mm}(300 \times 300 \mathrm{DPI})$ 


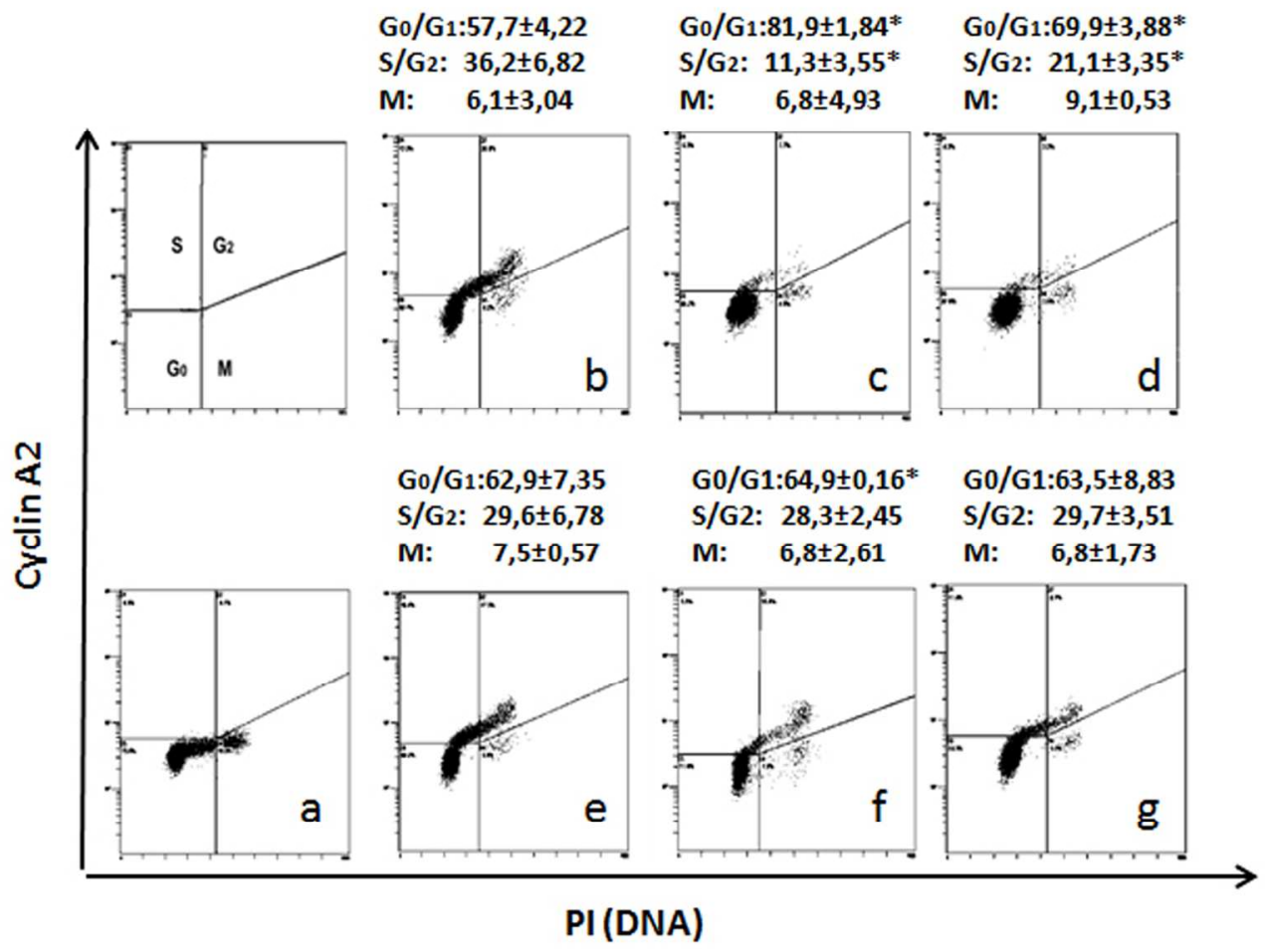

Fig. 6. Distribution of EA.hy 926 cells according to their cycling state upon 24-hr culturing in: a) culture medium, isotype control; b) culture medium (control); c) culture medium with SLS 1:50; d) culture medium with $3 \mu \mathrm{g} / \mathrm{ml} \mathrm{AD;} \mathrm{e)} \mathrm{culture} \mathrm{medium} \mathrm{with} 4 \mathrm{mM} \mathrm{L-Arg} ; \mathrm{f}$ ) culture medium with SLS 1:50 and $4 \mathrm{mM} \mathrm{L-Arg;} \mathrm{g)}$ culture medium with $3 \mu \mathrm{g} / \mathrm{ml} \mathrm{AD}$ and $4 \mathrm{mM} \mathrm{L-Arg}$. Asterisk marks the statistically significant difference from the control, $\mathrm{p}<0.05$.

$162 \times 121 \mathrm{~mm}(300 \times 300 \mathrm{DPI})$ 